\title{
Groundwater quality assessment using geospatial and statistical tools in Salem District, Tamil Nadu, India
}

\author{
P. Arulbalaji ${ }^{1}$ B. Gurugnanam ${ }^{1}$
}

Received: 29 December 2015/ Accepted: 9 November 2016/Published online: 22 November 2016

(c) The Author(s) 2016. This article is published with open access at Springerlink.com

\begin{abstract}
The water quality study of Salem district, Tamil Nadu has been carried out to assess the water quality for domestic and irrigation purposes. For this purpose, 59 groundwater samples were collected and analyzed for $\mathrm{pH}$, electrical conductivity (EC), total dissolved solids (TDS), major anions $\left(\mathrm{HCO}_{3}^{-}, \mathrm{CO}_{3}^{-}, \mathrm{F}^{-}, \mathrm{Cl}^{-}, \mathrm{NO}_{2}^{-}+\mathrm{NO}_{3}^{-}\right.$, and $\left.\mathrm{SO}_{4}{ }^{2-}\right)$, major cations $\left(\mathrm{Ca}^{2+} \mathrm{Mg}^{2+}, \mathrm{Na}^{+}\right.$, and $\mathrm{K}^{+}$), alkalinity (ALK), and hardness (HAR). To assess the water quality, the following chemical parameters were calculated based on the analytical results, such as Piper plot, water quality index (WQI), sodium adsorption ratio (SAR), magnesium hazard (MH), Kelly index (KI), and residual sodium carbonate (RSC). Wilcox diagram represents that $23 \%$ of the samples are excellent to good, $40 \%$ of the samples are good to permissible, $10 \%$ of the samples are permissible to doubtful, $24 \%$ of the samples are doubtful unsuitable, and only $3 \%$ of the samples are unsuitable for irrigation. SAR values shows that $52 \%$ of the samples indicate high-to-very high and low-to-medium alkali water. KI values indicate good quality $(30 \%)$ and not suitable (70\%) for irrigation purposes. RSC values indicate that $89 \%$ of samples are suitable for irrigation purposes. $\mathrm{MH}$ reveals that $17 \%$ suitable and $83 \%$ samples are not suitable for irrigation purposes and for domestic purposes the excellent $(8 \%)$, good $(48 \%)$, and poor $(44 \%)$. The agricultural waste, fertilizer used, soil leaching, urban runoff, livestock waste, and sewages are the sources of
\end{abstract}

P. Arulbalaji

arulbalajigeo@gmail.com

B. Gurugnanam

gurugis4u@gmail.com

1 Centre for Applied Geology, Gandhigram Rural InstituteDeemed University, Dindigul 624302, Tamil Nadu, India poor water quality. Some samples are not suitable for irrigation purposes due to high salinity, hardness, and magnesium concentration. In general, the groundwater of the Salem district was polluted by agricultural activities, anthropogenic activities, ion exchange, and weathering.

Keywords Geochemistry - Water quality index - Wilcox diagram $\cdot$ Kelley index $\cdot$ Magnesium hazard $\cdot$ Residual sodium carbonate $\cdot$ USSL diagram

\section{Introduction}

The groundwater chemistry is the essential factor, which is permitting its use for irrigation, domestic, and industrial. Most of the population in the world depends on groundwater for daily uses. More and more researchers are concentrating on hydro-geochemistry in recent decades, which is challenging to the scientific researchers based on hydrology and lithology (Guettaf et al. 2014; Kumar et al. 2014; Singh et al. 2014a, b; Srinivasamoorthy et al. 2011). The hydro-geochemical method can be used for identifying the interaction between rocks and waters (Basavarajappa and Manjunatha 2015; Qiyan and Baoping 2002; Zhang et al. 2001; Poroshin and Khaninak 2000; Cai et al. 1997). Developing countries, such as India, have extensive spectral differences of topographical, hydrological, meteorological, geomorphological, hydro-geological, and geological conditions (Kumar et al. 2015; Ahamed et al. 2013; Singh et al. 2014a, b). Groundwater origin, occurrence, and migrations depend upon several factors, such as drainage density, slope, geology, geomorphology, land use, and lineament density (Rajaveni et al. 2015). Groundwater, clean and safe in ancient days in contrast to present decades, shows how quick industrialization creates severe 
environmental issues in most countries (Santhosh and Revathi 2014). Once the groundwater is contaminated, it is very tough to recover its quality. Water in a few villages in Gangavalli Taluk in Salem district had a high hardness and fluoride content, characteristics which may be altered with softening and defluoridation, making the water useful (Florence et al. 2013). In Yercaud Taluk in Salem district, the groundwater conditions were good except fluoride content, which was more than the permissible limit by WHO (Florence et al. 2012). Geographic information system (GIS) is a valuable tool for mapping the water quality and effective for monitoring, which is used as a database system to create maps of water quality based on concentration values of various chemical constituents (Krishnaraj et al. 2015; Lozano et al. 2012). The aim of the present study is to demarcate the groundwater quality of the study area using geospatial and geostatistical tools.

\section{Materials and methods}

The groundwater quality data of the year 2014 were collected from the Public Work Department, State Ground and Surface Water Resources data center, Chennai. The physico-chemical characterization of the groundwater samples is evaluated with $\mathrm{pH}, \mathrm{EC}$, TDS, major anions $\left(\mathrm{HCO}_{3}{ }^{-}, \mathrm{F}^{-}\right.$, $\mathrm{Cl}^{-}, \mathrm{NO}_{3}{ }^{-}$, and $\left.\mathrm{SO}_{4}{ }^{2-}\right)$, major cations $\left(\mathrm{Ca}^{2+}, \mathrm{Mg}^{2+}, \mathrm{Na}^{+}\right.$, and $\mathrm{K}^{+}$), alkalinity, and hardness (Table 1). The analyzed data were compared with World Health Organization (WHO 2006) and Bureau of Indian Standards (BIS 2012) for suitability of domestic uses. SPSS 16.0 software was used to prepare the correlation matrix of the groundwater parameters. For identification of water types, the data are plotted in the piper diagram using the AquaChem 2012.1 software. In addition, evaluation of water quality parameters for suitability of irrigation was analyzed in Wilcox, SAR, RSC, Kelly index, and magnesium hazard.

Wilcox diagram was prepared using sodium percentage and $\mathrm{EC}$ value. The $\mathrm{Na} \%$ is determined by the following formula:

$\mathrm{Na} \%=\mathrm{Na}+\mathrm{K} /(\mathrm{Ca}+\mathrm{Mg}+\mathrm{Na}+\mathrm{K}) \times 100$.

The SAR was evaluated by the following formula:

$\mathrm{SAR}=\mathrm{Na} /[(\mathrm{Ca}+\mathrm{Mg}) / 2]^{0.5}$.

RSC values were assessed by the following formula:

$\mathrm{RSC}=\left(\mathrm{CO}_{3}+\mathrm{HCO}_{3}\right)-(\mathrm{Ca}+\mathrm{Mg})$.

Kelly index was analyzed by the following formula: $\mathrm{KI}=\mathrm{Na} /(\mathrm{Ca}+\mathrm{Mg})$.

Magnesium hazard values were measured by the following formula:

$\mathrm{MH}=\mathrm{Mg} /(\mathrm{Ca}+\mathrm{Mg}) \times 100$.

\section{Study area}

The present study concentrates on Salem district, Tamil Nadu, India, which is located North latitude between $11^{\circ} 14^{\prime}$ and $12^{\circ} 53^{\prime}$ and East longitude between $77^{\circ} 44^{\prime}$ and $78^{\circ} 50^{\prime}$. Salem district is one of the largest cities in respect to the Tamil Nadu population after Chennai, Coimbatore, Madurai, and Thiruchirappalli. The 2011 census recorded the population of 826,267 people. The total area covered by $5234 \mathrm{~km}^{2}$ and the average mean sea level is $278 \mathrm{~m}$. The study area is covered by hills, such as Jarugumalai, Nagaramalai, Kanjamalai, Kariyaperumal, Shervaroy, and Godumalai. There are two major river system flows which are the Cauvery and Vellar. The study area has a tropical climate. During the period November to January, the study area has a pleasant weather. In general, morning times are more humid than the afternoons, with the humidity above $75 \%$ on an average. During the period of June to November, the afternoon humidity is above $60 \%$ on an average. The total study area has a nine taluks and 653 villages. Salem district water sample location map is given in Fig. 1.

Geology of the area serves as the basis for groundwater condition and its occurrences, movement, and quality of groundwater (Rajaveni et al. 2015). Lithology of the study area exposes a highly dissected Precambrian shield terrain comprising rocks of diverse origin. In general, the area is made up of high-grade supra crystals of Archean age, comprising Khondalite group, Charnockite group and Satyamangalam group, and Younger intrusive alkaline syenite-carbonatite complex, ultramafics, basic, and acid rocks. The geological formation of Salem district is comprised of hard rock types of gneiss, granites, charnockite, dunite, pyroxenite, and quartzite, and the mineral formations are magnesite, bauxite, quartz, feldspar, soapstone, and limestone (Florence et al. 2013). The study area highly disturbed with a number of folds, lineaments, faults, shears, and joints (Srinivasamoorthy et al. 2011). Fissile Hornblende Biotite Gneiss and Charnockite are the major rock types in the study area.

\section{Results and discussion}

\section{pH}

$\mathrm{pH}$ is the expression of acidity or basic nature of a solution. The hydrogen ion concentrations in a solution determine the pH. The BIS (2012) and WHO (2006) have suggested that the limit of $\mathrm{pH}$ in drinking water is 7.0-8.5 and $6.5-8.5$, respectively. In study area, the $\mathrm{pH}$ ranges from 7.7 to 9 and the mean value is 8.59 (Table 2). According to the BIS (2012) and WHO (2006) standard, the study area 


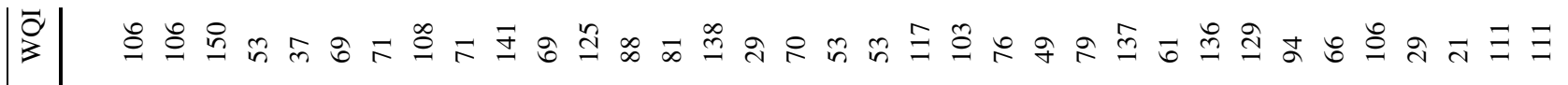
死 $\square$ กิ

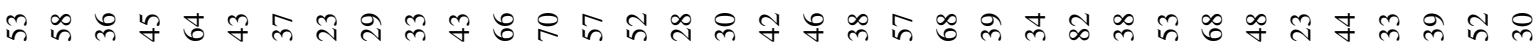

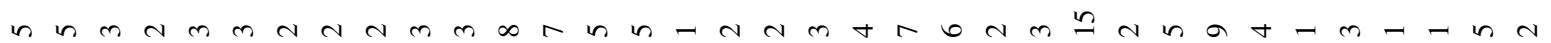

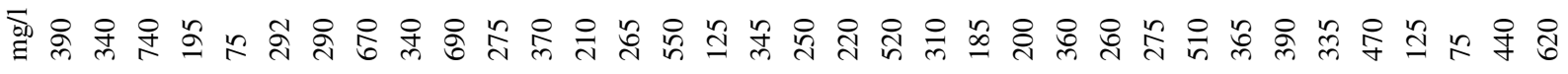

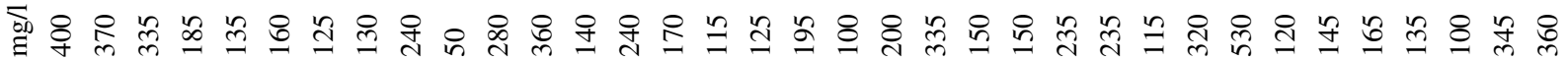

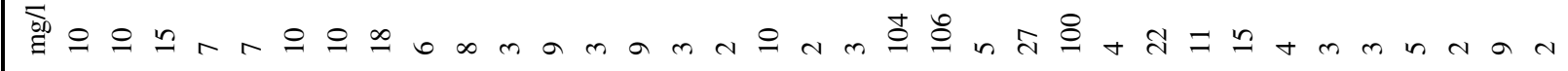
亞穴

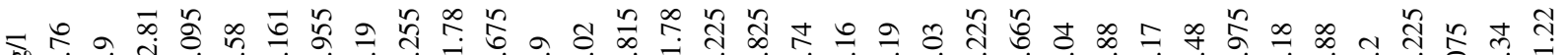

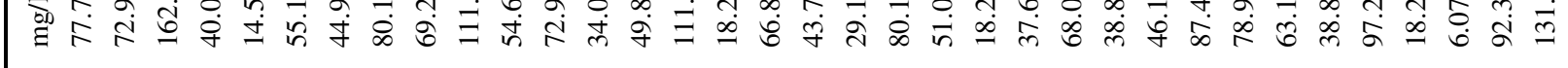

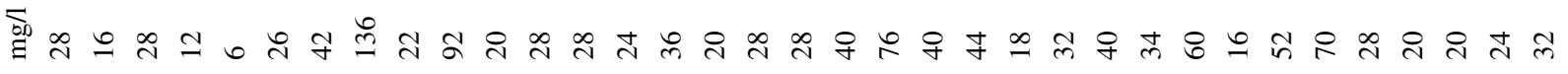

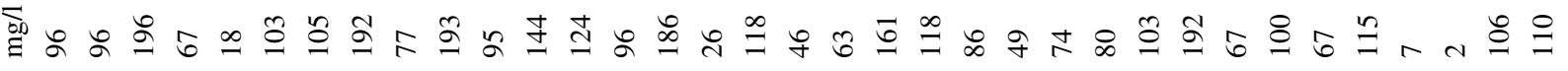

घิ

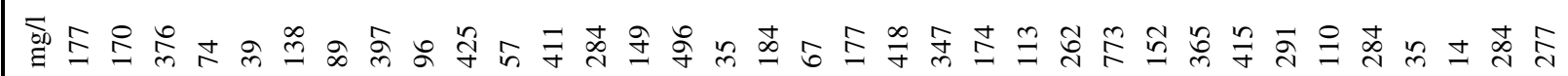

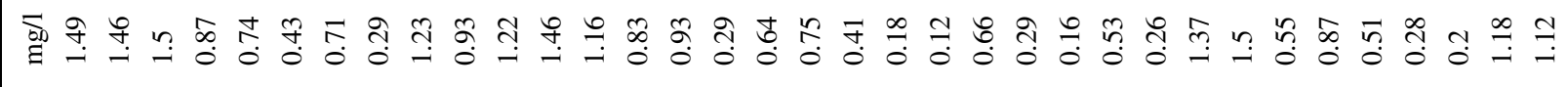

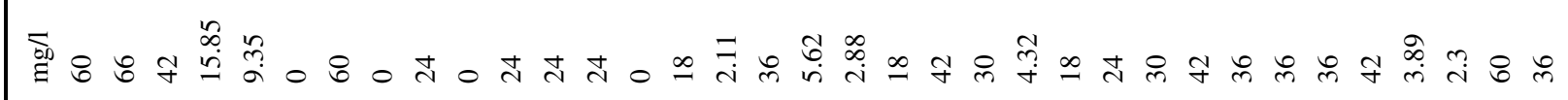
bo 氙 \&

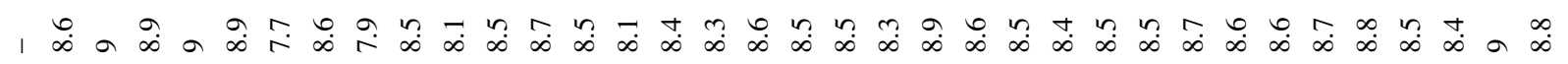

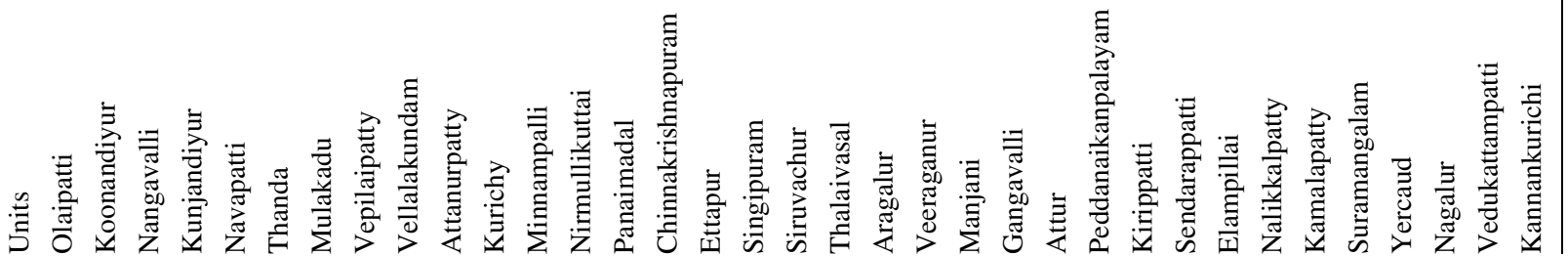




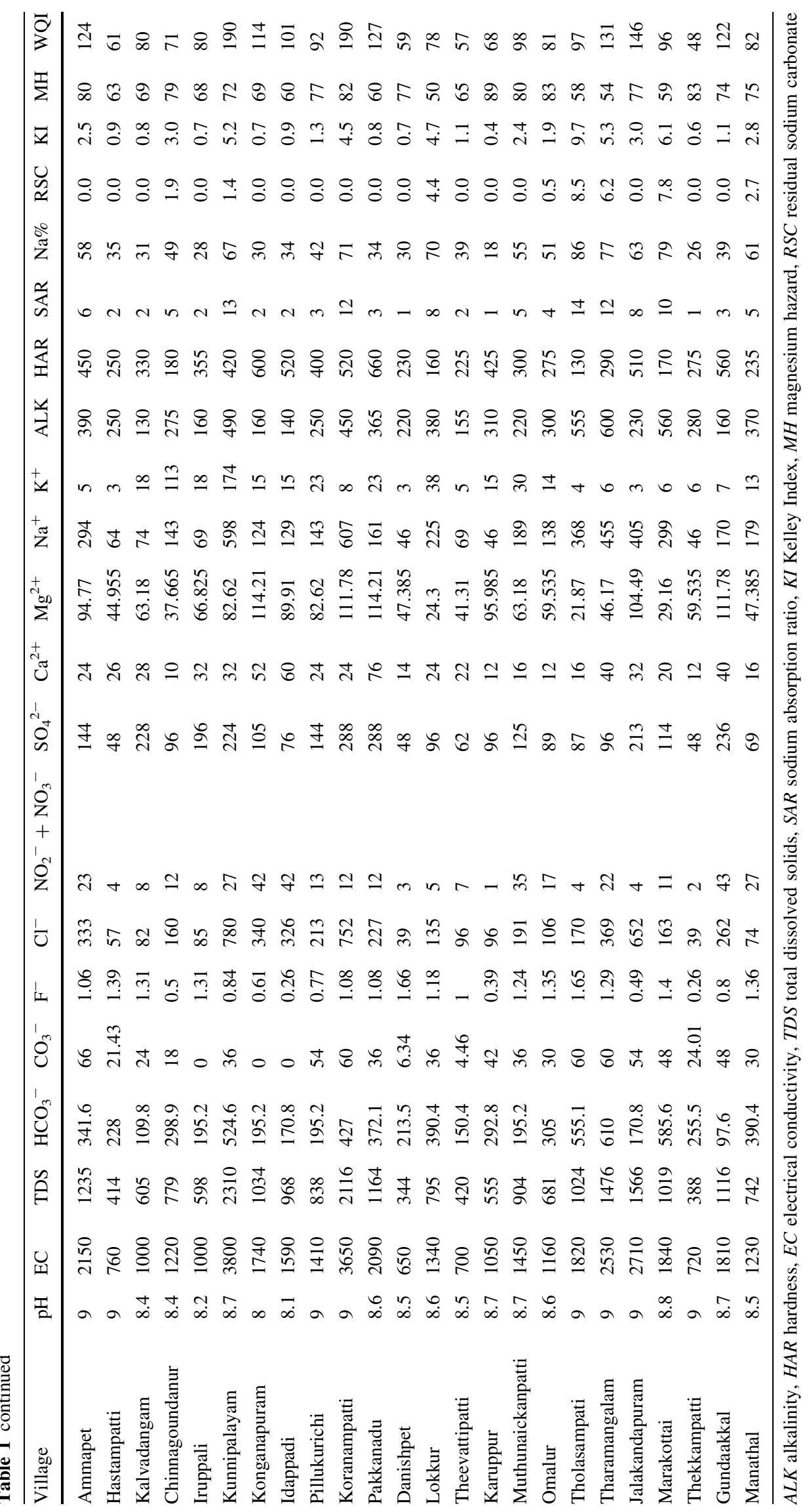




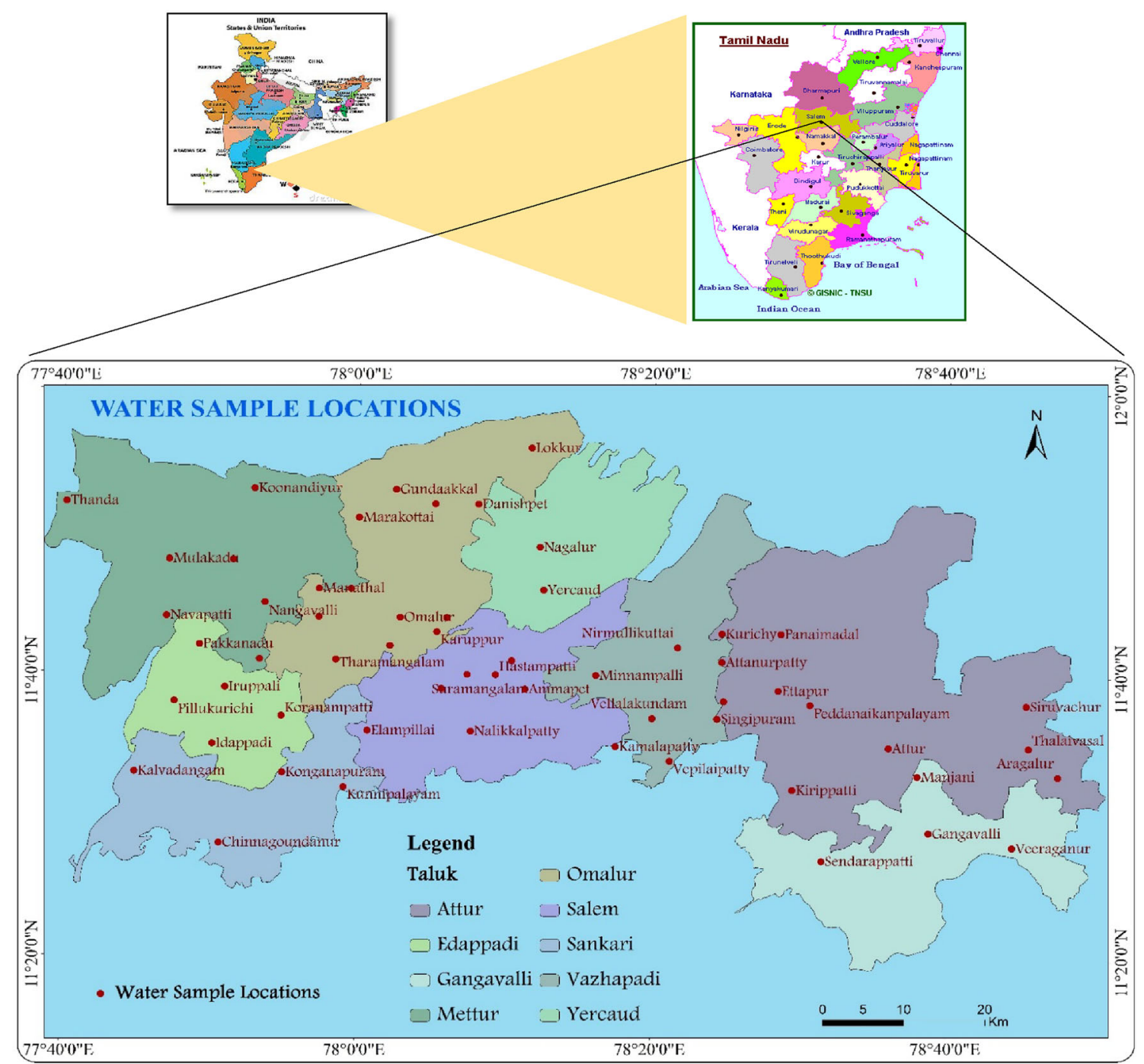

Fig. 1 Water sample location map of the study area

villages Thanda, Iruppali, Idappadi, Konganapuram, Kalvadangam, Chinnagoundanur, Nagalur, Panaimadal, Kurichy, Attanurpatty, Ettapur, Attur, Vepilaipatty, and Aragalur have a desirable limit of $\mathrm{pH}$ and the rest of the villages have above $8.5 \mathrm{pH}$. Excess amount of $\mathrm{pH}$ in the drinking water will affect the mucous membrane and water supply system (Napacho and Manyele 2010).

\section{Electrical conductivity}

$\mathrm{EC}$ is a measurement of the ability of an aqueous solution to carry an electrical current. EC measurement used for a number of applications related to water quality. These are to determine mineralization, changes in natural water and waste water quickly, and determining amounts of chemical reagents to be added to a water sample. In the study area, EC value ranges from 230 to $3800 \mu \mathrm{S} / \mathrm{cm}$ and the mean value is $1487 \mu \mathrm{S} / \mathrm{cm}$ (Table 2). The WHO (2006) guideline has suggested that the limit of EC in drinking water is 750 $\mu \mathrm{S} / \mathrm{cm}$. According to the WHO (2006) standard, the study area villages Ettapur, Theevattipatti, Danishpet, Nagalur, Yercaud, Kunjandiyur, Navapatti, Thekkampatti, Hastampatti, Vellalakundam, Kamalapatty, Kirippatti, Gangavalli, Siruvachur, Thalaivasal, and Kurichy have a desirable limit of EC in drinking water, and the rest of the villages have excess amount of EC in drinking water.

\section{Total dissolved solids}

TDS in water can originate from natural sources, livestock waste, sewage, nature of the soil, and urban run-off industrial wastewater. The concentration of dissolved matter in water is given by the weight of the material on evaporation of water to dryness followed by heating for $1 \mathrm{~h}$ at $180{ }^{\circ} \mathrm{C}$. The BIS (2012) has suggested that the acceptable limit of TDS in drinking water is $500 \mathrm{mg} / \mathrm{l}$ and 
Table 2 Comparison of the analytical data with WHO and BIS for domestic purposes

\begin{tabular}{|c|c|c|c|c|c|c|c|}
\hline \multirow[t]{2}{*}{ Parameters } & \multirow{2}{*}{$\begin{array}{l}\text { WHO (2006) } \\
\text { Maximum desirable limit }\end{array}$} & \multicolumn{2}{|c|}{ BIS 2012 (IS-10500) } & \multirow[t]{2}{*}{ Maximum } & \multirow[t]{2}{*}{ Minimum } & \multirow[t]{2}{*}{ Mean } & \multirow[t]{2}{*}{ Standard deviation } \\
\hline & & Acceptable limit & Permissible limit & & & & \\
\hline $\mathrm{pH}$ & $7-8.5$ & $6.5-8.5$ & No relaxation & 9 & 7.7 & 8.5 & 0.3 \\
\hline $\mathrm{EC}$ & 750 & - & - & 3800 & 230 & 1487 & 757 \\
\hline $\mathrm{CO}_{3}^{-}$ & - & - & - & 66 & 0 & 28 & 20 \\
\hline $\mathrm{HCO}_{3}^{-}$ & 200 & 200 & 600 & 610 & 30.5 & 244.7 & 140.6 \\
\hline $\mathrm{F}^{-}$ & $0-1.5$ & 1 & 1.5 & 1.66 & 0.12 & 0.87 & 0.4 \\
\hline $\mathrm{Cl}^{-}$ & 250 & 250 & 1000 & 780 & 14 & 235 & 185 \\
\hline $\mathrm{NO}_{3}^{-}$ & 50 & 45 & No relaxation & 60 & 1 & 16.6 & 14 \\
\hline $\mathrm{SO}_{4}{ }^{2-}$ & 200 & 200 & 400 & 288 & 2 & 113 & 64 \\
\hline $\mathrm{Na}^{+}$ & 200 & - & - & 607 & 23 & 179.5 & 138 \\
\hline $\mathrm{Ca}^{2+}$ & 75 & 75 & 200 & 136 & 6 & 32.7 & 22 \\
\hline $\mathrm{Mg}^{2+}$ & 30 & 30 & 100 & 162.8 & 6 & 64.73 & 32.8 \\
\hline $\mathrm{K}^{+}$ & 200 & - & - & 174 & 2 & 19 & 32.6 \\
\hline TDS & 500 & 500 & 2000 & 2310 & 135 & 872 & 445 \\
\hline HAR & 300 & 200 & 600 & 740 & 75 & 348 & 160 \\
\hline ALK & - & 200 & 600 & 600 & 50 & 252.4 & 131 \\
\hline SAR & - & - & - & 15 & 1 & 4 & 3 \\
\hline $\mathrm{Na} \%$ & - & - & - & 86 & 18 & 47 & 17 \\
\hline $\mathrm{RSC}$ & - & - & - & 9 & 0 & 1 & 2 \\
\hline Kelly index & - & - & - & 10 & 0 & 2 & 2 \\
\hline Magnesium hazard & - & - & - & 89 & 23 & 66 & 15 \\
\hline WQI & - & - & - & 243 & 18 & 93 & 42 \\
\hline
\end{tabular}

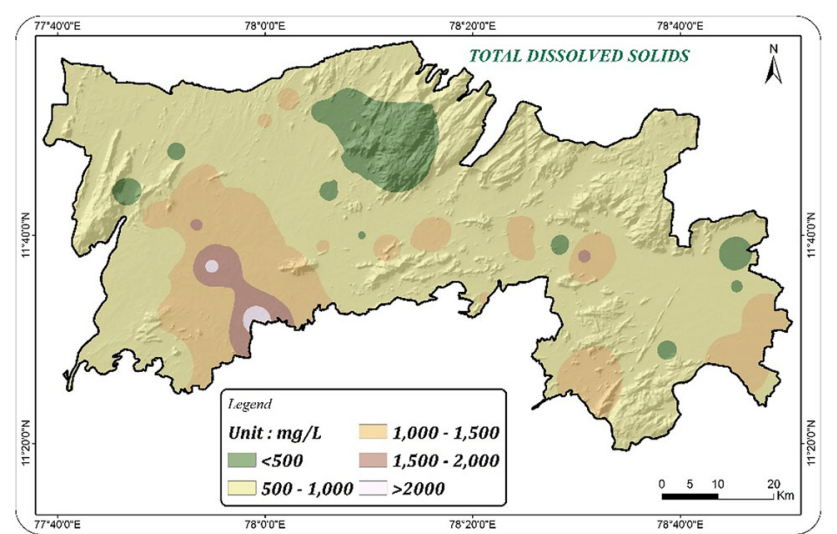

Fig. 2 Spatial distribution map of TDS

permissible limit of TDS in drinking water is $2000 \mathrm{mg} / \mathrm{l}$. In the study area, the TDS ranges from 135 to $2310 \mathrm{mg} / \mathrm{l}$ and the mean value is $872 \mathrm{mg} / \mathrm{l}$ (Table 2). The spatial distribution of the TDS is given in Fig. 2. According to the Indian standard the study area, villages Danispet, Nagalur, Yercaud, Kunjandiyur, Navapatti, Ettapur, Siruvachur, Thalaivasal, and Gangavalli have desirable amount of TDS in drinking water and rest of the villages except Koranampatti and Kunnipalayam have a permissible limit of TDS in drinking water. Koranampatti and Kunnipalayam villages have not permissible limit of TDS. The excess amount of TDS concentration is due to weathering and agricultural runoff of the study area.

\section{Bicarbonate}

Ecologically, bicarbonate is formed by the daylight photosynthetic activity of freshwater plants releasing gaseous oxygen into the water which simultaneously produces bicarbonate ions. The WHO (2006) has suggested that the limit of bicarbonate is $200 \mathrm{mg} / \mathrm{l}$. In the study area, the bicarbonate ranges from 30.5 to $610 \mathrm{mg} / \mathrm{l}$ with a mean value of $244.7 \mathrm{mg} / \mathrm{l}$ (Table 2). According to the WHO (2006) guidelines, the study areas Navapatti, Thanda, Mulakadu, Vepilaipatty, Attanurpatty, Nirmullikuttai, Chinnakrishnapuram, Ettapur, Singipuram, Siruvachur, Thalaivasal, Manjani, Gangavalli, Kirippatti, Nalikkalpatty, Kamalapatty, Suramangalam, Yercaud, Nagalur, Kalvadangam, Iruppali, Konganapuram, Idappadi, Pillukurichi, Theevattipatti, Muthunaickanpatti, Jalakandapuram, and Gundaakkal have desirable levels of bicarbonate in water. 


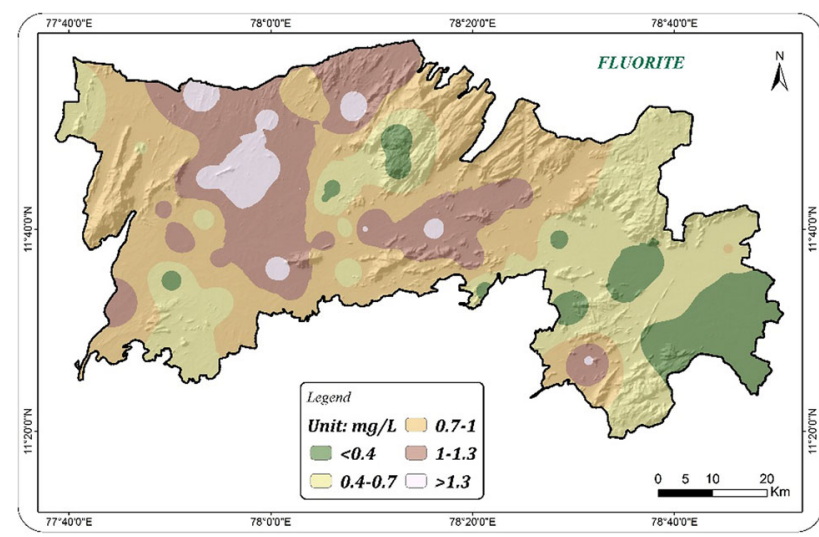

Fig. 3 Spatial distribution map of fluoride

\section{Carbonate}

Most of the carbonate ions in ground water are derived from the carbon di-oxide in the atmosphere and soil. The study area showed the highest carbonate concentration in $66 \mathrm{mg} / \mathrm{l}$ at Koonandiyur, Thanda, Vepillaipatti, Attanurpatty, Panaimadal, Iruppali, and Konganapuram, with Idappadi villages having neutral carbonate content in water.

\section{Fluoride}

Fluoride ions can occur either naturally or artificially in drinking water, and are absorbed to some degree in the bone structure of the body and tooth enamel. The BIS (2012) suggested that the highest desirable limit of fluoride content in drinking water is $1 \mathrm{mg} / \mathrm{l}$ and the permissible limit is $1.5 \mathrm{mg} / \mathrm{l}$. Excess amounts of fluoride compounds cause corrosion of piping and other water treatment equipment. In the study area, fluoride concentration ranges from 0.12 to $1.66 \mathrm{mg} / \mathrm{l}$ and the mean value is $0.87 \mathrm{mg} / \mathrm{l}$ (Table 2). The spatial distribution of fluoride concentration of the study area is given in Fig. 3. According to the BIS (2012) and WHO (2006) standards, the study area villages Thanda, Mulakadu, Kunjandiyur, Navapatti, Pillukurichi, Idappadi, Chinnagoundanur, Konganapuram, Kunnipalayam, Gundaakkal, Thekkampatti, Karuppur, Suramangalam, Nalikkalpatty, Yercaud, Nagalur, Panaimadal, Attanurpatty, Singipuram, Kamalapatty, Vepillaipatty, Kirippatti, Ettapur, Peddanaikanpalayam, Attur, Manjani, Gangavalli, Veeraganur, Aragalur, Thalaivasal, and Siruvachur have desirable levels of fluoride content in the drinking water and the villages Manathal, Nangavalli, Elampillai, Koranampatti, Iruppali, Pakkanadu, Kalvadangam, Omalur, Marakottai, Vedukattampatti, Hastampatti, Kannankurichi, Ammapet, Vellalakunda, Minnampalli, Nirmullikuttai, Kurichy, Sendarappatti, Koonandiyur, and Lokkur have high but permissible levels of fluoride content in the drinking water. The villages Danishpet and

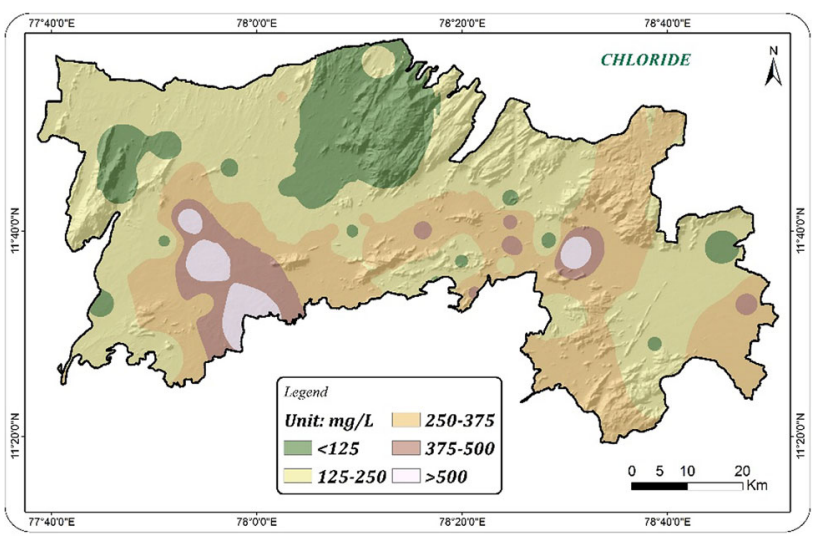

Fig. 4 Spatial distribution map of chloride

Tholasampati have the highest fluoride levels, which can lead to fluorosis diseases (Singh et al 2014a, b; Tiwari and Singh 2014). The excess amount of fluoride concentration in the study area is due to weathering and leaching of the high availability of fluoride minerals, such as amphiboles, apatite, biotite, and lepidolite.

\section{Chloride}

Chloride is the combination of the gas chlorine with a metal and is a minor constituent of the earth's crust but a major dissolved constituent of most natural waters. There are several sources of chloride in water, including agricultural runoff, rocks, wastewater from industries, road salting, and effluent wastewater from wastewater treatment plants (Guettaf et al. 2014). Chloride can contaminate freshwater and lakes. In the study area, the chloride ranges from 14 to $780 \mathrm{mg} / \mathrm{l}$ and the mean value is $235.6 \mathrm{mg} / \mathrm{l}$ (Table 2). The WHO (2006) standard of chloride acceptable limit in drinking water is $250 \mathrm{mg} / \mathrm{l}$. The spatial distribution map of the chloride ion is given in Fig. 4. Based on the WHO (2006) standard guideline, the study area villages Thanda, Koonandiyur, Marakottai, Mulakadu, Kunjandiyur, Navapatti, Pakanadu, Iruppali, Pillukurichi, Kalvadangam, Chinnagoundanur, Manathal, Tholasampati, Omalur, Muthunaickanpatti, Marakottai, Danispet, Nagalur, Yercaud, Lokkur, Karuppur, Thekkampatti, Hastampatti, Vellalakundam, Kamalapatty, Kurichy, Panaimadal, Ettapur, Kirippatti, Gangavalli, Manjani, Siruvachur, Thalaivasal, and Vellalakundam fall under the safe zone. Rest of the villages have excess amount from permissible limit. The excess amount of chloride in groundwater is due to weathering of rocks in the study area.

\section{Nitrite and nitrate}

Nitrate and nitrite concentration range from 1 to $60 \mathrm{mg} / \mathrm{l}$. The mean value is $16.6 \mathrm{mg} / \mathrm{l}$ (Table 2). The WHO (2006) 


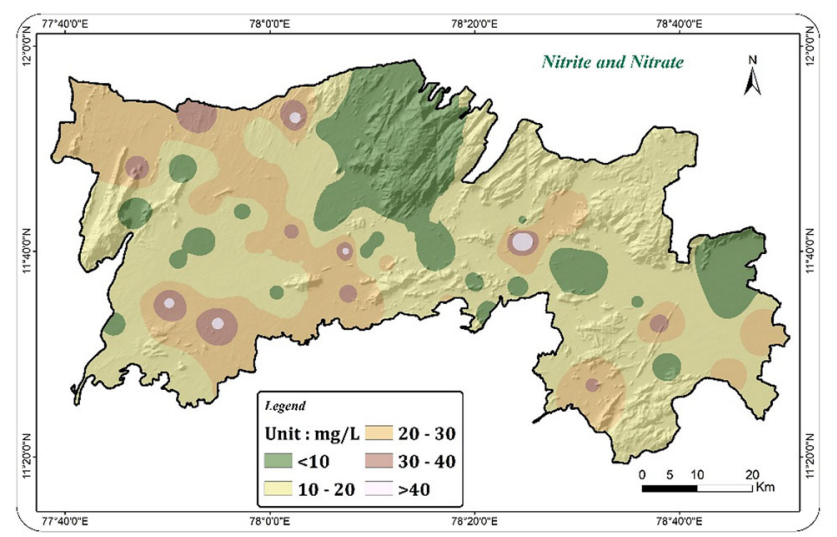

Fig. 5 Spatial distribution map of nitrite and nitrate

desirable limit of nitrate and nitrite concentration is $50 \mathrm{mg} /$ 1. The spatial distribution of nitrate and nitrite concentration is given in Fig. 5. According to the WHO (2006) standard, it falls under the safe zone except Attanurpatty. The excess concentration of nitrate and nitrite concentration can produce the "brown blood disease". These extreme amounts of nitrate and nitrite concentration mixed with water may occur through fertilizer runoff, animal wastes, leaking septic tanks, sanitary landfills, industrial waste waters, and discharge from car exhausts (Singh et al. $2014 a, b)$. The excess amount of nitrite and nitrate concentration in attanurpatty is due to agricultural activities, such as high use of fertilizer in the study area.

\section{Sulfate}

Sulfate can be naturally occurring through rock or soil and other common minerals or formed artificially from runoff of fertilized agriculture lands. Sulfur is an important plant nutrient. The BIS (2012) and WHO (2006) have suggested that the desirable limit of sulfate is $200 \mathrm{mg} / \mathrm{l}$ and permissible limit is $400 \mathrm{mg} / \mathrm{l}$. In the study area, the sulfate ranges from 2 to $288 \mathrm{mg} / \mathrm{l}$, and the mean value is $113.4 \mathrm{mg} / \mathrm{l}$ (Table 2). According to Indian Standard the study area, villages except Pakkanadu, Jalakandapuram, Koranampatti, Kummipalayam, Kalvadangam, and Gundaakkal fall below the desirable limits and all other villages fall below the permissible limits. Sulfate is not considered toxic at normal concentrations; very high sulfate is toxic to cattle.

\section{Calcium}

Calcium ranges from 6 to $136 \mathrm{mg} / \mathrm{l}$, and the mean value is $32.7 \mathrm{mg} / \mathrm{l}$ (Table 2). The BIS (2012) and WHO (2006) have suggested that the desirable limit of calcium concentration ion in the drinking water is $75 \mathrm{mg} / \mathrm{l}$. According to the BIS (2012), the study area villages except Vepillaipatty, Kamalapatty, Aragalur, Attanurpatty, and
Pakkanadu fall under the safe zone. Most part of the study area covered by low and very low calcium concentrations. Plagioclase feldspar and clinopyroxene are the main source of the calcium content in the study area. These are characteristically found in Charnockite rock. The Charnockite rock is generally high in the study area. The variations in topography, surface material (rock and soil), and land cover which influence the rate of weathering are the reasons for the differences in the concentration of calcium in the waters of the study area (Kumar et al. 2014).

\section{Magnesium}

The magnesium ranges from 6 to $162 \mathrm{mg} / \mathrm{l}$, and the mean value is $64.7 \mathrm{mg} / \mathrm{l}$ (Table 2). The drinking water specification in the BIS (2012) and WHO (2006) has suggested that the desirable limit of the magnesium in water is $30 \mathrm{mg} / \mathrm{l}$ and the BIS (2012) permissible limit in the absence of an alternate source is $100 \mathrm{mg} / \mathrm{l}$. (Rosanoff 2013) has stated that Universal drinking water and beverages containing moderate-to-high levels of magnesium (10-100 ppm) could potentially prevent 4.5 million heart disease and stroke deaths per year, worldwide, and this potential is calculated with 2010 global mortality figures combined with a recent quantification of water-magnesium inverse association with heart disease and stroke mortality. The spatial distribution map of the magnesium ion concentration is shown in Fig. 6. According to the above said standard, the magnesium ion concentration of study area villages Navapatti, Ettapur, Thalaivasal, Manjani, Yercaud, Nagalur, Lokkur, Tholasampatti, and Marakottai falls below the desirable limit and that of the rest of the villages except Nangavalli, Attanurpatty, Chinnakrishnapuram, Kannankurich Konganapuram, Koranampatti, Pakkanadu, Jalakandapuram, and Gundakkal fall within the permissible limit in the absence of alternative sources. The above said except villages fall under the above desirable level. The source of high

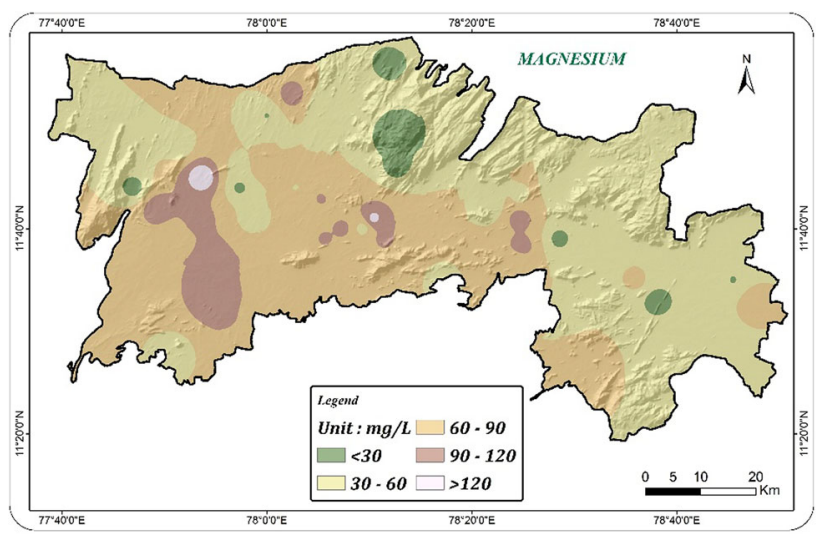

Fig. 6 Spatial distribution map of magnesium 


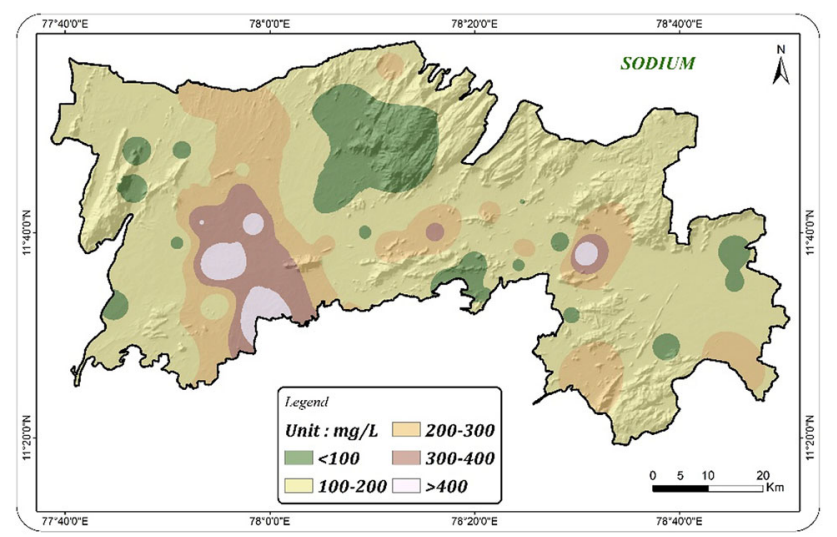

Fig. 7 Spatial distribution map of sodium

magnesium level in the groundwater is due to magnesite deposits and ultramafic rock occurrence of the study area. Natural water contains magnesium and calcium, which caused hardness of groundwater based on dissolved polyvalent metallic ions (Basavarajappa and Manjunatha 2015).

\section{Sodium}

Sodium is a very reactive and it does not occur in its free form in nature. The primary source of the sodium in the water is the weathering of plagioclase feldspars and clinopyroxenes which are essential constituents of the charnockite. Healthbased guideline by the WHO 2006 has suggested the sodium ion in water be $200 \mathrm{mg} / \mathrm{l}$. In the study area, the sodium ion ranges from 23 to $607 \mathrm{mg} / \mathrm{l}$ and the mean value is $179.5 \mathrm{mg} / \mathrm{l}$ (Table 2). The spatial distribution map of the sodium ion concentration is shown in Fig. 7. According to the WHO2006 standard the study area, villages Thanda, Mulakadu, Kunjandiyur, Navapatti, Kalvadagam, Chinnagoundanur, Idappadi, Pillukurichi, Pakkanadu, Iruppali, Nangavalli, Konganapuram, Manathal, Gundakkal, Danishpet, Nagalur, Yercaud, Karuppur, Thekkampatti, Muthunaickanpatti, Omalur, Suramangalam, Kannankurichi, Hastampatti, Nalikkalpatty, Vellalakundam, Kamalapatty, Vepilaipatty, Singipuram, Kirippatti, Gangavalli, Attur, Aragalur, Thalaivasal, Siruvachur, Attanurpatty, Kurichy, and Panaimadal fall under the permissible limits and the rest of the villages have excess amount of sodium concentration. The excess amount of sodium ion in water can produce the high blood pressure and pregnant women suffering from toxemia (Haritash et al. 2014). The excess amount of sodium concentration in the study area is due to weathering of charnockite rock.

\section{Potassium}

Potassium is an alkali metal which is abundant in minerals of the earth's crust. The potash feldspar is an essential constituent of charnockite, and the rock type of the area is the major source for the presence of potassium in the subsurface water of the study area. In the study area, the potassium ranges from 2 to $174 \mathrm{mg} / \mathrm{l}$ and the mean value is $19 \mathrm{mg} / \mathrm{l}$ (Table 2). The WHO (2006) suggested that the permissible level of potassium is $200 \mathrm{mg} / \mathrm{l}$. According to the WHO-2006 standard, the study area villages fall under the safe zone.

\section{Alkalinity}

Alkalinity or buffering capacity refers to capability of water to neutralize acid. Alkalinity is related to the hardness, because carbonate rocks are a main source of alkalinity. The BIS (2012) guideline has suggested that the total alkalinity of drinking water is $200-600 \mathrm{mg} / \mathrm{l}$. In the study area, total alkalinity ranges from 50 to $600 \mathrm{mg} / \mathrm{l}$ and the mean value is $252 \mathrm{mg} / \mathrm{l}$ (Table 2). According to the BIS (2012) standard, the study area villages have an allowable limit of total alkalinity. The excess alkalinity levels in surface water lead to acid rain and can be harmful to aquatic life.

\section{Hardness}

The amount of calcium and magnesium in water is called hardness of water. In general, surface water is softer than ground water. The WHO (2006) suggested that the desirable limit of hardness in drinking water is $300 \mathrm{mg} / \mathrm{l}$. In the study area, the hardness value ranges from 75 to $745 \mathrm{mg} / \mathrm{l}$ and the mean value is $348 \mathrm{mg} / \mathrm{l}$ (Table 2). The spatial distribution map of the hardness content in the study area is given in Fig. 8. The study area villages Nagalur, Yercaud, and Navapatti are containing a moderately hard water, Mulakadu, Thanda, Kunjandiyur, Marakottai, Danishpet, Lokkur, Nirmullikuttai, Mnanthal, Tholasampati, Chinnagoundanur, Thekkampatti, Hastampatti, Kurichy, Panaimadal, Ettapur, Peddanaikanpalayam, Kirippatti, Manjani,

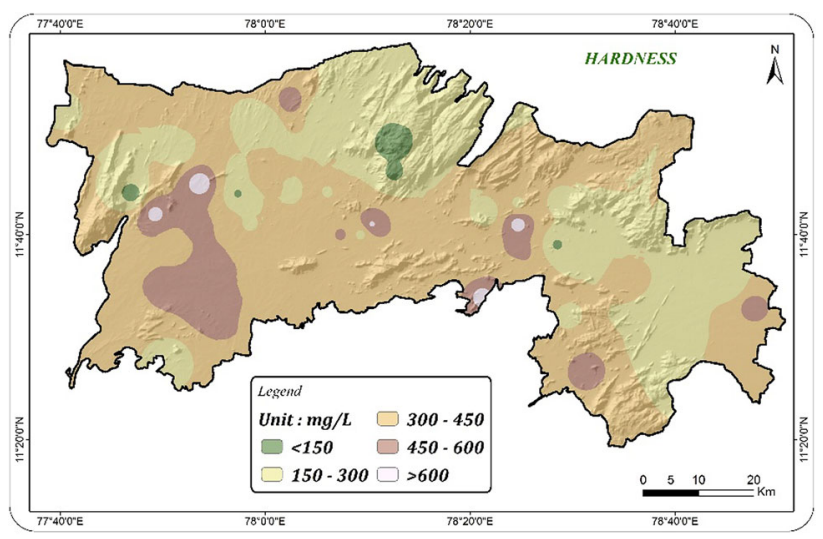

Fig. 8 Spatial distribution map of hardness 
Table 3 Correlation matrix of water quality parameters

\begin{tabular}{|c|c|c|c|c|c|c|c|c|c|c|c|c|c|c|c|}
\hline Parameters & $\mathrm{pH}$ & $\mathrm{EC}$ & TDS & $\mathrm{HCO}_{3}^{-}$ & $\mathrm{CO}_{3}^{-}$ & $\mathrm{F}^{-}$ & $\mathrm{Cl}^{-}$ & $\mathrm{NO}_{2}^{-}+\mathrm{NO}_{3}^{-}$ & $\mathrm{SO}_{4}{ }^{2-}$ & $\mathrm{Ca}^{2+}$ & $\mathrm{Mg}^{2+}$ & $\mathrm{Na}^{+}$ & $\mathrm{K}^{+}$ & ALK & $\overline{\mathrm{HAR}}$ \\
\hline $\mathrm{pH}$ & 1 & & & & & & & & & & & & & & \\
\hline $\mathrm{EC}$ & 0.22 & 1.00 & & & & & & & & & & & & & \\
\hline TDS & 0.20 & 1.00 & 1.00 & & & & & & & & & & & & \\
\hline $\mathrm{HCO}_{3}{ }^{-}$ & 0.36 & 0.55 & 0.51 & 1.00 & & & & & & & & & & & \\
\hline $\mathrm{CO}_{3}^{-}$ & 0.74 & 0.49 & 0.47 & 0.46 & 1.00 & & & & & & & & & & \\
\hline $\mathrm{F}^{-}$ & 0.33 & 0.21 & 0.18 & 0.53 & 0.39 & 1.00 & & & & & & & & & \\
\hline $\mathrm{Cl}^{-}$ & 0.09 & 0.93 & 0.93 & 0.29 & 0.27 & -0.03 & 1.00 & & & & & & & & \\
\hline $\mathrm{NO}_{2}{ }^{-}+\mathrm{NO}_{3}^{-}$ & -0.15 & 0.34 & 0.39 & -0.10 & 0.19 & 0.04 & 0.26 & 1.00 & & & & & & & \\
\hline $\mathrm{SO}_{4}{ }^{2-}$ & 0.03 & 0.69 & 0.70 & 0.15 & 0.33 & 0.20 & 0.59 & 0.32 & 1.00 & & & & & & \\
\hline $\mathrm{Ca}^{2+}$ & -0.41 & 0.27 & 0.29 & -0.22 & -0.17 & -0.25 & 0.35 & 0.38 & 0.42 & 1.00 & & & & & \\
\hline $\mathrm{Mg}^{2+}$ & 0.07 & 0.59 & 0.57 & 0.13 & 0.29 & 0.16 & 0.52 & 0.44 & 0.68 & 0.30 & 1.00 & & & & \\
\hline $\mathrm{Na}^{+}$ & 0.34 & 0.90 & 0.90 & 0.63 & 0.51 & 0.27 & 0.84 & 0.15 & 0.45 & 0.01 & 0.24 & 1.00 & & & \\
\hline $\mathrm{K}^{+}$ & -0.07 & 0.32 & 0.36 & 0.23 & 0.00 & -0.28 & 0.31 & 0.10 & 0.20 & 0.07 & 0.04 & 0.25 & 1.00 & & \\
\hline ALK & 0.51 & 0.56 & 0.53 & 0.98 & 0.62 & 0.55 & 0.29 & -0.08 & 0.17 & -0.26 & 0.15 & 0.66 & 0.19 & 1.00 & \\
\hline HAR & -0.09 & 0.59 & 0.58 & 0.03 & 0.18 & 0.05 & 0.56 & 0.50 & 0.72 & 0.60 & 0.94 & 0.20 & 0.06 & 0.04 & 1 \\
\hline
\end{tabular}

Gangavalli, Thalaivasal, and Siruvachur contain hard water, and the rest of the villages contain very hard water. For the drinking purposes, Nagalur, Yercaud, Navapatti, Mulakadu, Thanda, Kunjandiyur, Marakottai, Danishpet, Lokkur, Nirmullikuttai, Mnanthal, Tholasampati, Chinnagoundanur, Thekkampatti, Hastampatti, Kurichy, Panaimadal, Ettapur, Peddanaikanpalayam, Kirippatti, Manjani, Gangavalli, Thalaivasal, and Siruvachur have desirable limit of Hardness in drinking water and rest of the villages except Nangavalli, Pakkanadu, and Attanurpatty have permissible limit of hardness in drinking water.

\section{Correlation matrix}

The correlation statistical method used to identify the connection and variation between the groundwater samples with the help of physico-chemical parameters and ionic concentrations (Kumar et al. 2015; Ahamed et al. 2013). The correlation matrix of the all groundwater variables is shown in Table 3. In general, the matrix values are in between -1 and +1 . EC and TDS show high positive correlation with $\mathrm{Cl}^{-}, \mathrm{SO}_{4}{ }^{2-}$, and $\mathrm{Na}^{+}$and moderate correlation with $\mathrm{HCO}_{3}{ }^{-}, \mathrm{Mg}^{2+}, \mathrm{ALK}$, and HAR. There is a good correlation between $\mathrm{HCO}_{3}{ }^{-}$and ALK (0.98), and $\mathrm{Cl}^{-}$ and $\mathrm{Na}^{+}(0.84)$, and moderate correlation between $\mathrm{Na}^{+}$and ALK (0.66), $\mathrm{SO}_{4}{ }^{2-}$ and $\mathrm{Mg}^{2+}$ (0.68), $\mathrm{Cl}^{-}$and $\mathrm{SO}_{4}{ }^{2-}$ (0.59), $\mathrm{F}^{-}$and $\operatorname{ALK}(0.55), \mathrm{CO}_{3}^{-}$and $\mathrm{Na}^{+}(0.51)$, and $\mathrm{CO}_{3}{ }^{-}$and ALK (0.62). Thus, the good correlation between the quality parameters indicates similar source and/or geochemical behavior during various processes (Tiwari et al. 2015). The positive correlations between $\mathrm{Cl}^{-}$and $\mathrm{Na}^{+}$(0.84), $\mathrm{Cl}^{-}$and TDS (0.93), and $\mathrm{Na}^{+}$and TDS (0.90) are derived from anthropogenic sources (Tiwari and Singh 2014). The high positive correlation between $\mathrm{Mg}^{2+}$ and HAR are derived from ultramafic rocks in the study area. The poor correlation between $\mathrm{Ca}^{2+}$ and $\mathrm{SO}_{4}{ }^{2-}(0.42)$ indicates that the gypsum dissolution could not be the major contributor for the dissolved ions in the water of the study area (Tiwari et al. 2015)

\section{Piper analysis}

Piper diagram is a way of visualizing graphical representation of chemistry in water samples in hydro-geological studies. The piper plot contained three pieces: these are lower left triangle diagram representing cations, lower right triangle diagram representing the anions, and a diamond plot in the middle representing a combination of the two. There are six ion groups considered in the piper plot, and they are calcium, magnesium and sodium plus potassium cations, and sulphate, chloride, and carbonate plus hydrogen carbonate anions. The study area water analysis result is plotted in piper diagram Fig. 9. According to the piper diagram, the villages Attanurpatty and Vellalapatty are dominant in Calcium-chloride type of water. The villages Tharamangalam, Elampillai, Chinnagoundanur, Veeraganur, Panaimadal, Minnampalli, Koranampatti, Manjani, Vedukattampatti, Danishpet, Chinnakrishnapuram, Sendarapatti, Jalakandapuram, Nirmullikuttai, and Kunnipalayam are dominant in the sodium chloride type of water. The calcium-chloride and sodium-chloride rich in these areas because of Fissile Hornblende Biotite gneiss and Charnockite are the parent rock, which have composed of sodium and calcium rich minerals. The villages Karuppur, 


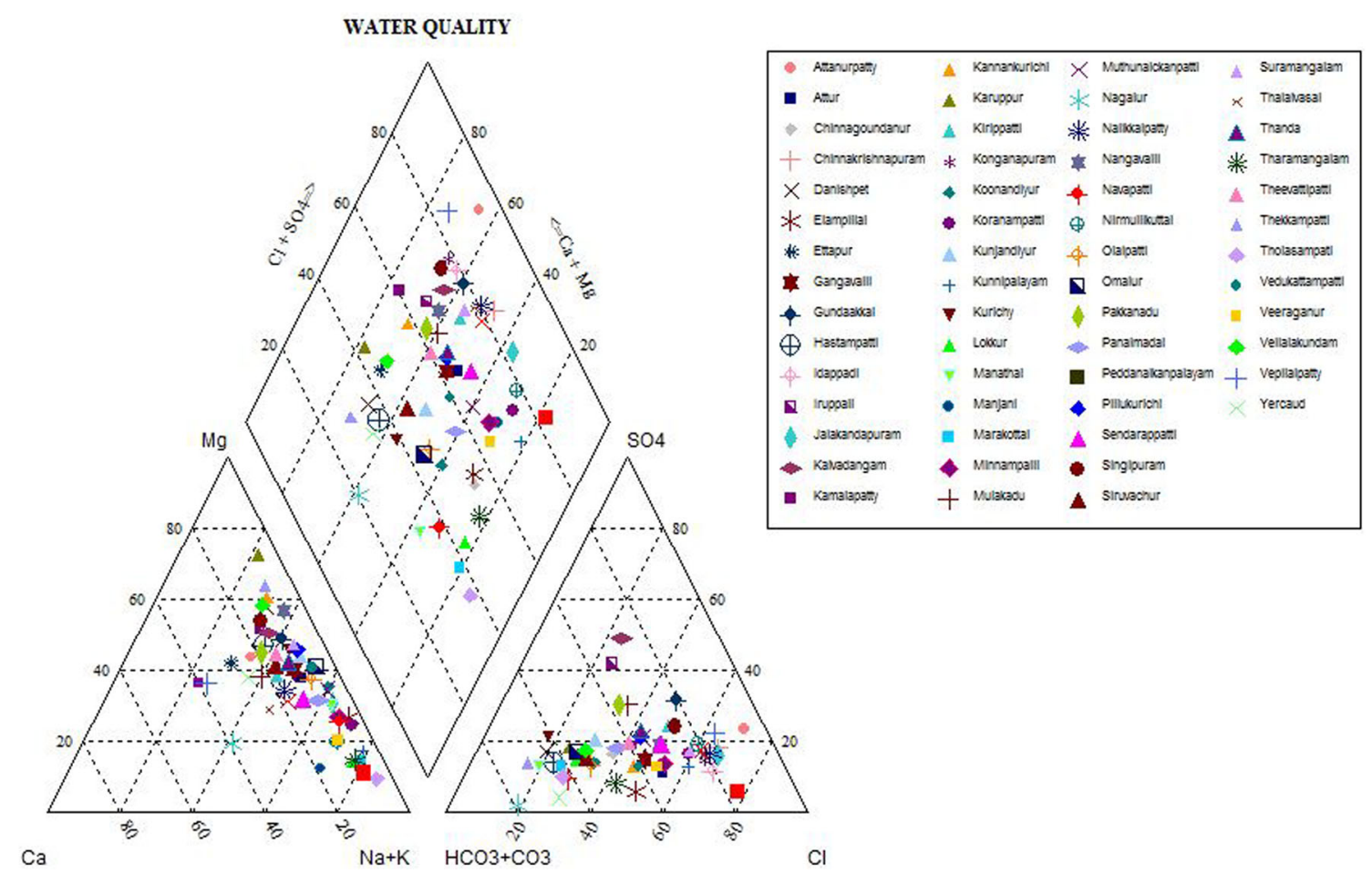

Fig. 9 Piper plot

Vellalakundam, Ettapur, Muthunaickanpatti, Thekkampatti, Hastampatti, Kurichy, Nagalur, Siruvachur, and Yercaud are dominant in the magnesium bicarbonate type of water, and because of these areas, they are influenced by magnesite deposits and ultramafic rocks. The villages Omalur, Olaipatti, Koonandiyur, Lokkur, Manathal, Marakottai, Tholasampatti, Navapatti, Attur, Gangavalli, Gundaakkal, Idappadi, Iruppalli, Kalvadangam, Kamalapatty, Kannankurichi, Kirippatti, Konganapuram, Kunjandiyur, Mulakadu, Nalikkalpatty, Nangavalli, Pakkandu, Peddanaikanpalayam, Pilluckurichi, Singipuram, Suramangalam, Thalaivasal, Thanda, and Theevattipatti are dominant in mixed type of water, which means no cations and anions exceeds $50 \%$.

\section{Water quality index}

WQI is a significant way to assess and monitor the quality of water in the current years due to its usefulness for the understanding of water quality issues by integrating complex data (Mishra and Patel 2001; Singh et al. 2013; Tiwari et al. 2015). For computing WQI, three steps were followed. In the first step, each of the 12 parameters $(\mathrm{pH}$, TDS, $\mathrm{F}^{-}, \mathrm{Cl}^{-}, \mathrm{NO}_{3}{ }^{-}, \mathrm{SO}_{4}{ }^{2-}, \mathrm{HCO}_{3}{ }^{-}, \mathrm{Ca}^{2+}, \mathrm{Mg}^{2+}, \mathrm{Na}^{+}$, $\mathrm{K}^{+}$, and HAR) has been assigned a weight (wi) according to its relative importance in the overall quality of water for drinking purposes (Table 4). The maximum weight of 5 has been assigned to the parameters, such as TDS, $\mathrm{Na}^{+}$, $\mathrm{F}^{-}, \mathrm{Cl}^{-}, \mathrm{NO}_{3}{ }^{-}$, and $\mathrm{SO}_{4}{ }^{2-}$, while $\mathrm{HCO}_{3}{ }^{-}$was assigned the minimum weight of 1 , as it plays an insignificant role in the water quality assessment and other parameters, such as $\mathrm{pH}$, $\mathrm{Ca}^{2+}, \mathrm{Mg}^{2+}, \mathrm{K}^{+}$, and HAR were assigned weights between 2 and 5 depending on their importance in water quality determination (Vasanthavigar et al. 2009; Tiwari et al.

Table 4 Relative weights of chemical parameters

\begin{tabular}{|c|c|c|c|}
\hline $\begin{array}{l}\text { Chemical } \\
\text { parameters }\end{array}$ & $\begin{array}{l}\text { Standards } \\
\text { (BIS/WHO) }\end{array}$ & Weight (wi) & $\begin{array}{l}\text { Relative weight } \\
\text { (WI) }\end{array}$ \\
\hline $\mathrm{pH}$ & 8.5 & 4 & 0.09 \\
\hline TDS & 500 & 5 & 0.11 \\
\hline $\mathrm{F}^{-}$ & 1 & 5 & 0.11 \\
\hline $\mathrm{Cl}^{-}$ & 250 & 5 & 0.11 \\
\hline $\mathrm{NO}_{3}^{-}$ & 45 & 5 & 0.11 \\
\hline $\mathrm{SO}_{4}{ }^{2-}$ & 200 & 5 & 0.11 \\
\hline $\mathrm{HCO}_{3}{ }^{-}$ & 200 & 1 & 0.02 \\
\hline $\mathrm{Ca}^{2+}$, & 75 & 3 & 0.07 \\
\hline $\mathrm{Mg}^{2+}$ & 30 & 3 & 0.07 \\
\hline $\mathrm{Na}^{+}$ & 200 & 5 & 0.11 \\
\hline $\mathrm{K}^{+}$ & 200 & 2 & 0.04 \\
\hline \multirow[t]{2}{*}{ HAR } & 500 & 2 & 0.04 \\
\hline & & $\Sigma w i=45$ & $\Sigma \mathrm{Wi}=1.00$ \\
\hline
\end{tabular}


2015). The weightage of $\mathrm{K}^{+}$has been assigned according to its relative importance of quality of water.

The second step is the calculate the relative weight (Wi) by the following equation:

$\mathrm{Wi}=\mathrm{wi} / \sum_{i=1}^{n} \mathrm{wi}$

where $\mathrm{Wi}$ is the relative weight, wi is the weight of each parameter, and $n$ is the number of parameters. The result of relative weight (Wi) is given in Table 4.

The third step is a quality rating scale (qi) for each parameter that is assigned by dividing its concentration in each water sample by its respective standard according to the guidelines laid down in the BIS 2012, and the result is multiplied by 100 (Vasanthavigar et al. 2009):

$\mathrm{qi}=(\mathrm{Ci} / \mathrm{Si}) \times 100$

where qi is the quality rating, $\mathrm{Ci}$ is the concentration of each chemical parameter in each water sample in milligrams per liter, and $\mathrm{Si}$ is the Indian drinking water standard for each chemical parameter in milligrams per liter according to the guideline of the BIS 2012.

For computing the WQI, the SI is first determined for each chemical parameter, which is then used to determine the WQI as per the following equation (Tiwari et al. 2015):

$\mathrm{SI}=\mathrm{Wi} \times \mathrm{qi}$

$\mathrm{WQI}=\sum \mathrm{SI} i$

where SI $i$ is the sub-index of $i$ th parameter, qi is the rating based on concentration of the $i$ th parameter, and $n$ is the number of parameters. WQI can be classified into five categories based on their value: excellent water $(<50)$, good water $(50-100)$, poor water $(100-200)$, very poor water (200-300), and unfit for drinking purpose $(>300)$ (Vasanthavigar et al. 2009; Tiwari et al. 2015). The WQI of Salem district ranges from 18 to 243 with a mean value of 42. Among the all groundwater samples, the percentage of WQI categories are excellent (8\%), good (48\%), and poor (44\%) for domestic uses (Fig. 10).

\section{Suitability of irrigation uses}

Wilcox The Wilcox (1955) diagram of the study area is given in Fig. 11. Based on Wilcox diagram, the results show that the following villages, such as Kunjandiyur, Navapatti, Ettapur, Siruvachur, Thalaivasal, Gangavali, Kamalapatty, Yercaud, Nagalur, Hastampatti, Danishpet, Teevattipatti, and Thekkampatti, fall below the excellent to good for irrigation water. The villages Olaipatti, Thanda, Mulakadu, Vepilaipatty, Vellalakundam, Kurichy, Singipuram, Attur, Kiripatti, Nalikkalpatty, Kannankurichi, Kalvadagam, Chinnagoundanur, Iruppali, Konganapuram,

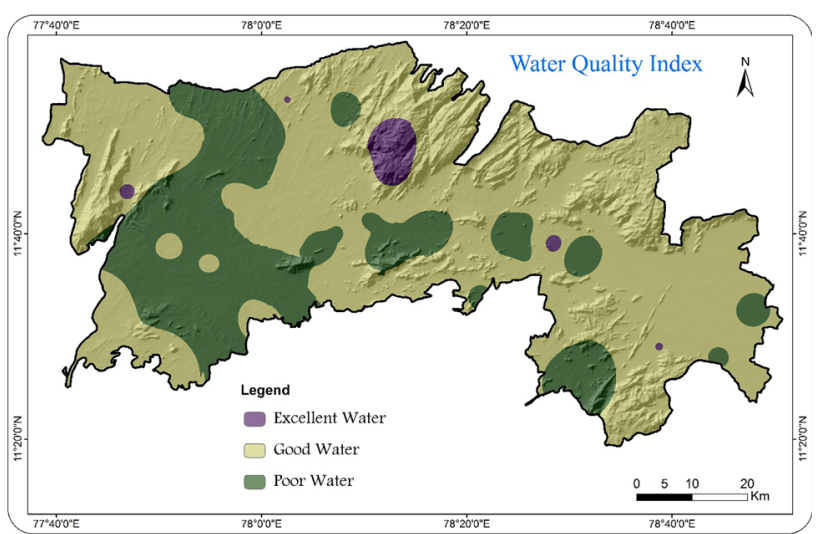

Fig. 10 WQI map for the Salem District, South India

Idappadi, Pillukurichi, Karruppur, Muthunaickanpatti, Omalur, Gundaakkal, Manathal, and Suramangalam fall below the good-to-permissible level. The permissible-todoubtful level of the villages is Koonandiyur, Nirmullikuttai, Manjani, Vedukattampatti, Lokkur, and Marakottai. Then, the unsuitable for irrigation level of water occurs in Kunnipalayam and Koranampatti villages in the study area. Rest of the villages fall below the doubtful-tounsuitable level.

Sodium adsorption ratio (SAR) USSL plot of the study area is given in Fig. 12. A high salt concentration in water leads to formation of saline soil and high sodium concentration may cause the development of an alkaline soil (Tiwari and Singh, 2014). On the basis of SAR value, water is classified into low (SAR $<6$ ), medium (SAR 6-12), high (SAR 12-18), and very high (SAR $>18$ ) alkali waters (Tiwari et al. 2016a). The SAR in the study area ranges from 1 to 15 (Table 2). According to USSL diagram, Nagalur village falls below the C1S1 level. Kunjandiyur, Navapatti, Ettapur, Siruvachur, Gangavalli, Yercaud, Danishpet, Theevattipatti, and Thekkampatti fall below the $\mathrm{C} 2 \mathrm{~S} 1$ level, and these categories are indicating that goodto-permissible quality of water for irrigation uses with little danger of development of exchangeable sodium and salinity (Tiwari et al. 2016a). C3S2 level covers Minnampalli, Nirmullikuttai, Veeraganur, Manjani, Ammapet, Lokkur, Sendarappatti, and Koonandiyur. C4S1 and C4S4 levels cover the Nangavalli and Peddanaikanpalayam, respectively. The villages Elampillai, Kunnipalayam, Koranampatti, and Thramangalam fall under the C4S3 level, and the villages Tholasampatti and Marakottai fall under the C3S3 level. The Jalakandapuram and Chinnakrishnapuram villages fall under the C4S2 level. Rest of the villages, such as Thanda, Mulakadu, Vepilaipatty, Vellalakundam, Attanurpatty, Kurichy, Singipuram, Thalaivasal, Aragalur, Attur, Kirippatti, Nalikkalpatty, Kamala patty, Suramangalam, Kannankurichi, Hastampatti, Kalvadangam, Irupali, Konganapuram, Idappadi, Pillukurichi, 


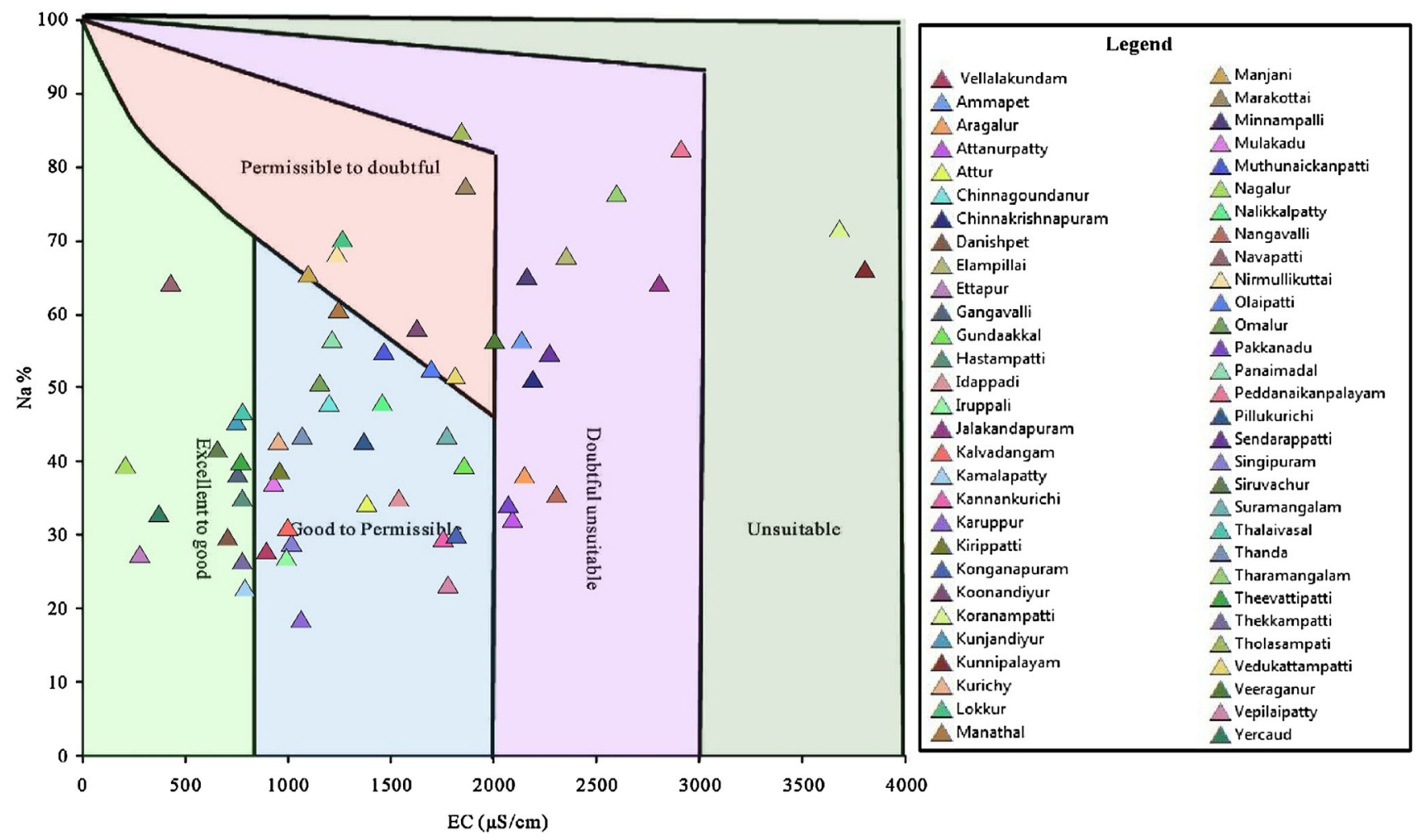

Fig. 11 Wilcox (1955) diagram for classification of groundwater based on $\mathrm{EC}$ and $\mathrm{Na} \%$

Pakkanadu, Karuppur, Omalur, Gundakkal, Manathal, Olaipatti, Panaimadal, Vedukattampatti, Chinnagoundanur, and Muthunaickanpatti, fall under the C3S1 levels. The zones of C4S2 and C3S1 indicate high-to-very high salinity and low-to-medium alkali water, which are not suitable for soils with restricted drainage and it requires a special management for salinity control (Sappa et al. 2014)

Residual sodium carbonate (RSC) RSC is measured to indicate the sodium hazard in water. Irrigation water having $>5$ RSC value is considered as harmful to the growth of plants, whereas water having $>2.5 \mathrm{RSC}$ value is not considered suitable for irrigation, and $<2.5 \mathrm{RSC}$ value is considered as suitable for irrigation (Tiwari et al. 2016b). The study area RSC value ranges from 0 to 9 with the mean value of 1 (Table 2). Tholasampatti, Tharamangalam, and Marakottai villages are harmful to growth of plant. Elampillai, Lokkur, and Manathal villages are considered as not suitable for irrigation. Rest of the villages are having RSC value below 2.5, which are suitable for irrigation.

Kelly index $(K I)$ Water with less than 1 Kelly's index value indicates suitable for irrigation (Kelley 1940; Paliwal 1967). Kelly index value of study area ranges from 0 to 10 with mean value of 2 (Table 2). The villages Vepilaipatty, Vellalakundam, Attanurpatty, Ettapur, Singipuram, Kamalapatty, Yercaud, Nagalur, Kannankurichi, Hastampatti, Kalvadangam, Iruppali, Konganapuram, Idappadi, Pakkanadu, Danishpet, Karuppur, and Thekkampatti (30\%) have good quality of groundwater for irrigation purposes. Rest of the $(70 \%)$ samples are not suitable for irrigation purposes based on KI value.

Magnesium hazard $(\mathrm{MH})$ The excess amount of $\mathrm{Mg}$ in the groundwater affects the quality of soil, resulting in poor agricultural returns (Tiwari et al. 2016b). Magnesium hazard in groundwater $>50$ is considered as harmful and unsuitable for irrigation use (Szabolcs and Darab 1964). The study area $\mathrm{MH}$ value ranges from 23 to 89 with a mean value of 66 (Table 2). Mulakadu, Vepilaipatty, Ettapur, Thalaivasal, Manjani, Peddanaikanpalayam, Kamalapatty, Yercaud, Nagalur, and Lokkur have a suitability of irrigation water. Rest of the (83\%) samples are not suitable for irrigation purposes based on $\mathrm{MH}$ value.

\section{Conclusion}

Water chemistry of the Salem district highly reflects the primary sources from weathering of rocks and its minerals, with secondary dominance of anthropogenic activities. The results of the investigation show that the following types of water dominates in the Salem district were calcium chloride type (4\%), magnesium bicarbonate type (18\%), sodium chloride type (27\%), and mixed type of water (51\%). Rock water interaction is the main sources of the chemical composition, and the study area predominantly 


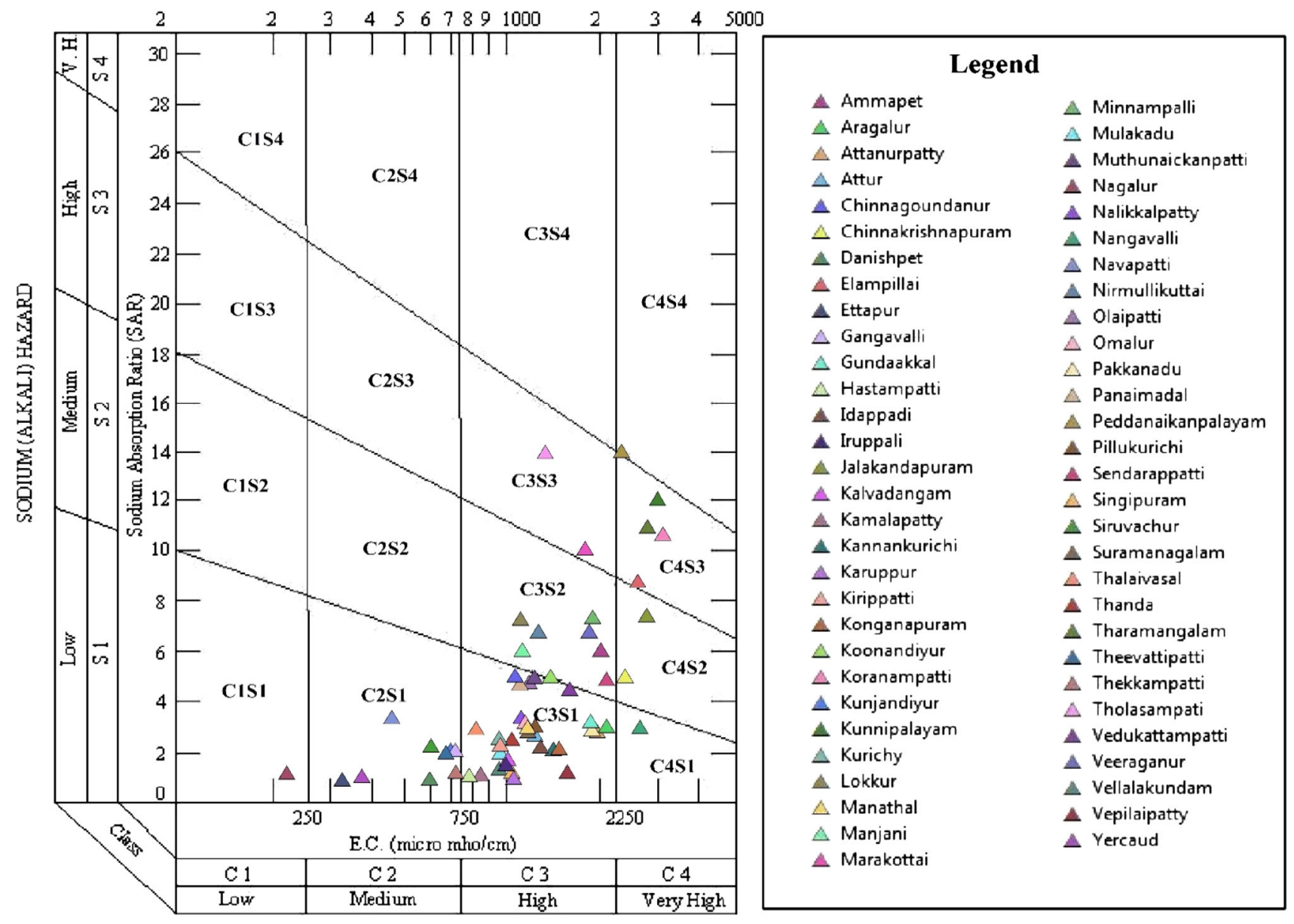

SAIINITY HAZARD

Fig. 12 USSL diagram for classification of irrigation

comprised by fissile hornblende biotite gneiss and charnockite.

The WQI results show excellent water (8\%), good water $(48 \%)$, and poor water (44\%) of samples for domestic and irrigation uses. $44 \%$ of poor water samples mostly were observed in the western part of the study area. The western part and other parts of poor water quality in the study area were obviously covered by agricultural land and settlement area. Due to these agricultural wastes, fertilizer used, soil leaching, sewage, livestock waste, and urban runoff were highly contaminated the groundwater. The total dissolved solid, anions $\left(\mathrm{F}^{-}, \mathrm{Cl}^{-}\right.$, and $\left.\mathrm{NO}_{3}{ }^{-}\right)$, and cations $\left(\mathrm{Mg}^{2+}\right.$ and $\mathrm{Na}^{+}$) are more responsible parameters of poor water quality for drinking purposes of the study area.

Some samples of groundwater in the study area are unsuitable for irrigation uses, because these samples have high salinity, hardness, and magnesium concentration. If it is used for irrigation, it will affect the plant growth and contaminate the quality of soil. In general, the impact of agricultural runoff, anthropogenic activities, ion exchange, and weathering is the sources of the groundwater pollution in the study area. In this situation, the following suggestions are necessary to manage the water quality of the study area. The farmers should take an effort to mitigate the effects of agricultural runoff. Government must initiate and create awareness of the vulnerability of high using fertilizers. Anthropogenic activities should be controlled by government, management, and maintenance and should carry over the water resources to break the contamination.

Acknowledgements The author thanks to the Public Work Department, State Ground, and Surface Water Resources data center, Chennai for providing the data resource of the Salem district, Tamil Nadu, India.

Open Access This article is distributed under the terms of the Creative Commons Attribution 4.0 International License (http:// creativecommons.org/licenses/by/4.0/), which permits unrestricted use, distribution, and reproduction in any medium, provided you give appropriate credit to the original author(s) and the source, provide a link to the Creative Commons license, and indicate if changes were made. 


\section{References}

Ahamed AJ, Ananthakrishnan S, Loganathan K, Manikandan K (2013) Assessment of groundwater quality for irrigation use in Alathur block, Perambalur district, Tamilnadu, South India. Appl Water Sci. 3:763-771

Basavarajappa HT, Manjunatha MC (2015) Groundwater quality analysis in Precambrian rocks of Chitradurga District, Karnataka, India using Geo-informatics Technique. Aquatic Procedia 4:1354-1365

Cai C, Li W, Zeng F (1997) Water-rock interaction in Tarim basin: constraints from oilfield water geochemistry. Chin J Geochem 16(4):289-303

Florence PL, Raj AP, Ramachandramoorthy T (2012) Water quality index and correlation study for the assessment of water quality and its parameters of Yercaud Taluk, Salem District, Tamil Nadu, India. Chem Sci Trans 1(1):139-149

Florence PL, Raj AP, Ramachandramoorthy T (2013) Ground water quality assessment of Gangavalli taluk, Salem district, Tamil Nadu, India using multivariate statistical techniques. IRACST 3 (1)

Guettaf M, Maoui A, Ihdene Z (2014) Assessment of water quality: a case study of the Seybouse River (North East of Algeria). Appl Water Sci. doi:10.1007/s13201-014-0245-z

Haritash AK, Gaur S, Garg S (2014) Assessment of water quality and suitability analysis of River Ganga in Rishikesh. Appl Water Sci, India. doi:10.1007/s13201-014-0235-1

Kelley WP (1940) Permissible composition and concentration of irrigation water. Proc Am Soc Civ Eng 66:607-613

Krishnaraj S, Kumar S, Elango KP (2015). Spatial analysis of groundwater quality using geographic information system-a case study. IOSR 9(2):01-06

Kumar VS, Amarender B, Dhakate R, Sankaran S, Kumar KR (2014) Assessment of groundwater quality for drinking and irrigation use in shallow hard rock aquifer of Pudunagaram, Palakkad District Kerala. Appl Water Sci. doi:10.1007/s13201-014-0214-6

Kumar SK, Logeshkumaran A, Magesh NS, Godson S, Chandrasekar N (2015) Hydro-geochemistry and application of water quality index (WQI) for groundwater quality assessment, Anna Nagar, part of Chennai city, Tamil Nadu, India. Appl Water Sci 5:335-343

Lozano R, Naghavi M, Foreman K, Lim S, Shibuya K, Aboyans V, Abraham J, Adair T, Aggarwal R, Ahn SY, Murray JL (2012) Global and regional mortality from 235 causes of death for 20 age groups in 1990 and 2010: a systematic analysis for the Global Burden of Disease Study 2010. Lancet 380(9859):2095-2128

Mishra PC, Patel RK (2001) Study of the pollution load in the drinking water of Rairangpur, a small tribal dominated town of North Orissa. Indian J Environ Ecoplan 5:293-298

Napacho ZA and Manyele SV (2010) Quality assessment of drinking water in Temeke district (part II): characterization of chemical parameters. AJEST 4(11):775-789

Paliwal KV (1967) Effect of gypsum application on the quality of irrigation waters. Madras Agric J 59:646-647

Poroshin VD, Khaninak VP (2000) Rock-water Interaction during the Exploitation of Oil Pools in Subsalt and Intersalt Rocks: the Pripyat Depression as an Example. Lithol Min Resour 35(5):484-492

Qiyan F, Baoping H (2002) Hydro geochemical simulation of waterrock interaction under water flood recovery in reniqu oilfield, Hebei province, China. Chin J Geochem 21(2)
Rajaveni SP, Brindha K, Elango L (2015) Geological and geomorphological controls on groundwater occurrence in a hard rock regions. Appl Water Sci. doi:10.1007/s13201-015-0327-6

Rosanoff A (2013) Changing crop magnesium concentrations: impact on human health. Plant Soil 368(1-2):139-153

Santhosh P, Revathi D (2014) Hydrogeochemical analysis of gorund water parameters in Coimbatore District, Tamil Nadu, India. Res J Chem Environ Sci 2(2):89-93

Sappa G, Ergul S, Ferranti F (2014) Water quality assessment of carbonate aquifers in southern Latium region, Central Italy: a case study for irrigation and drinking purposes. Appl Water Sci. $4: 115-128$

Shouting Z, Pengda Z, Zhanzhang X, Minghua Z (2001) Water/Rock interactions and changes in Chemical composition during Zeolite Mineralization. Chin J Geochem 20(3)

Singh PK, Tiwari AK, Panigarhy BP, Mahato MK (2013) Water quality indices used for water resources vulnerability assessment using GIS technique: a review. Int $J$ Earth Sci Eng 6(6-1):1594-1600

Singh N, Verma KG, Verma P, Sidhu GK, Sachdeva S (2014a) A comparative study of fluoride ingestion levels, serum thyroid hormone and TSH level derangements, dental fluorosis status among school children from endemic and non-endemic fluorosis areas. Springer Plus 3:7

Singh UV, Abhishek A, Singh KP, Dhakate R, Singh NP (2014b) Groundwater quality appraisal and its hydrochemical characterization in Ghaziabad (a region of indo-gangetic plain), Uttar Pradesh, India. Appl Water Sci. 4:145-157

Srinivasamoorthy K, Nanthakumar C, Vasanthavigar M, Vijayaraghavan K, Rajivgandhi R, Chidambaram S, Anandhan P, Manivannan R, Vasudevan S (2011) Groundwater quality assessment from a hard rock terrain, Salem district of Tamilnadu, India. Arab J Geosci 4:91-102

Szabolcs I, Darab C (1964) The influence of irrigation water of high sodium carbonate content of soils. In: Proceedings of 8th international congress of ISSS, transmission, vol 2, pp 803-812

Tiwari AK, Singh AK (2014) Hydrogrochemical investigation and groundwater qualtiy assessment of Pratapgarh District, Uttar Pradesh. J Geol Soc India 83(3):329-343

Tiwari AK, Singh AK, Singh AK, Singh MP (2015) Hydrogeochemical analysis and evaluation of surface water quality of Pratapgarh district, Uttar Pradesh, India. Appl Water Sci. doi:10.1007/ s13201-015-0313-z

Tiwari AK, Singh PK, Mahato MK (2016a) Environmental geochemistry and a quality assessment of mine water of the West Bokaro Coalfield, India. Mine Water Environ. doi:10.1007/ s10230-015-0382-0

Tiwari AK, Maio MD, Singh PK, Singh AK (2016b) Hydrogeochemical characterization and groundwater quality assessment in a coal mining area, India. Arab J Geosci 9(3):1-17

Vasanthavigar M, Srinivasamoorthy K, Vijayaragavan K, Gandhi RR, Chidambaram S, Anandhan P, Manivannan R, Vasudevan S (2009) Application of water quality index for groundwater quality assessment: Thirumanimuttar sub-basin Tamilnadu. Environ Monit Assess, India. doi:10.1007/s10661-009-1302-1

WHO (World Health Organization) (2006) Guideline for drinking water quality. Water quality parameters and drinking water standards-2012 (IS: 10500) 